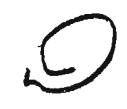

$$
304: 378(81)
$$

\title{
As Reformas Sociais e a Faculdade de Direito.
}

\author{
Manifesto de professôres.
}

"Professôres de Direito e com plena consciência de nossas responsabilidades, queremos manifestar pùblicamente a nossa adesão irrestrita à campanha social iniciada por sua eminência o Cardeal Arcebispo dom Carlos Carmelo de Vasconcellos Motta.

Visando, com a sua campanha, a proporcionar o conhecimento fiel da doutrina social da Igreja e preparando, dêste modo, o ambiente propício á sua aplicação, sua eminência demonstrou eloqüentemente, em sua mensagem de primeiro de maio, que á Igreja incumbe exercer função propulsora na solução dos magnos problemas humanos. Sua eminência demonstrou, também, que êstes problemas só e ùnicamente podem ser resolvidos mediante o respeito aos fundamentos espirituais e morais de nossa religião, que hão-de exercer preeminência decisiva na graduação dos valores das fôrças sociais e na disciplina de seu equilíbrio baseada em sã justiça distributiva.

Vinda dos ensinamentos dos evangelhos e exposta nas monumentais encíclicas Rerum Novarum, Quadragésimo Anno e Mater et Magistra, a doutrina da Igreja é eterna, porque os princípios que a informam, inerentes à própria natureza humana e animados pelo espírito do cristianismo, bem se ajustam às contingências sociais de todos os tempos. É doutrina fundada no amor e não no ódio; na aspiração de uma vida individual e social mais justa e não no aniqüilamento da pessoa, nem na destruição da família, menos ainda 
na escravização de povos livres. É a doutrina da verdadeira liberdade e da verdadeira democracia alicerçadas na justiça sucial.

Ao assinalar as transformações sociais verificadas entre a Rerum Novarum e o Quadragesimo Anno e entre esta e o momento em que dirigiu à cristandade sua própria mensagem de paz social, sua santidade o Papa João XXIII, considerou os problemas sociais contemporâneos em seu todo, na unidade em que se juntam e entrelaçam, e não como problemas independentes, que porventura comportassem soluções isoladas; e isto porque, afetando o indivíduo, os mesmos problemas atingem a família e os grupos sociais e com êstes a própria sociedade, sob todos os aspectos de sua vida espiritual, educacional, política, econômica.

$\mathrm{Na}$ verdade, são múltiplos os problemas que, à míngua de solução, vêm minando a nossa paz social: - problemas institucionais, problemas de saúde e educação, problemas financeiros criados pelo encilhamento com a riqueza de alguns e a miséria de muitos, problemas de encarecimento constante da vida, problemas de regiões desafortunadas, onde a fome e as moléstias imperam e as convulsões se fazem propícias à ação dos agitadores, problemas de habitação das populações das favelas e dos porões, problemas rurais a exigirem imediatamente, uma reforma agrária que dê ao homem terra e assistência, problemas de justa remuneração do trabalhador do campo e das cidades, com melhor distribuição dos lucros das emprêsas e outros e outros problemas mais, que, todos, se conjugam e só podem ser solucionados à luz dos princípios de fraternidade, de justiça social, dos princípios, isto é, genialmente expostos na Mater et Magistra e cuja aplicação é necessária sob pena de perecimento da nossa civilização cristã.

De há muito sua eminência o cardeal arcebispo dom Carlos Carmelo de Vasconcellos Motta vem aconselhando a adoção de medidas que atendam às nossas necessidades 
sociais mais prementes e agora, com a sua notável oração de primeiro de maio, a todos nos conclama para a batalha da realização dessas reformas.

Nós, professôres de Direito, atendemos ao seu chamado de guia e pastor e estamos ao seu lado, porque, juristas e católicos que somos, não concebemos como possa haver ordem jurídica sem ordem social justa e inspirada pelos ensinamentos cristãos sôbre os quais se construiu e em razão dos quais sôbrevive a nossa própria civilização.

São Paulo, 8 de maio de 1962".

Subscrevem o manifesto os professôres: Luís Antonio da Gama e Silva, Vicente Rao, Ernesto de Moraes Leme, Honório Monteiro, Antônio Ferreira Cesarino Júnior, Basileu Garcia, José Carlos de Ataliba Nogueira, Miguel Reale, Theotonio Monteiro de Barros Filho, Goffredo da Silva Telles Júnior, Sylvio Marcondes, Alfredo Buzaid, Moacir Amaral Santos, Washington de Barros Monteiro, Nicolau Nazo, João de Deus Cardoso de Mello, Paulo Barbosa de Campos Filho, José Loureiro Júnior, Antônio Chaves, José Frederico Marques, Vicente Marotta Rangel, Sílvio Rodrigues, Oscar Barreto Filho, João Bernardino Garcia Gonzaga, Fernando Henrique Mendes de Almeida, Celso Neves, Luís Ambra, Guilherme Percival de Oliveira, João Baptista de Oliveira e Costa Júnior, Paulo Carneiro Maia, Otto de Sousa Lima e José Luiz de Anhaia Mello. 